\title{
FAKTOR YANG MEMPENGARUHI PERBEDAAN NILAI PROFESIONAL PERAWAT PADA MAHASISWA PROFESI NERS KELAS KHUSUS
}

\section{FACTORS THAT INFLUENCE THE DIFFERENCE OF NURSING PROFESSIONAL VALUE IN SPECIAL CLASSROOM PROFESSIONAL STUDENTS}

\author{
Tri Hartiti ${ }^{1}$ Muhammad Zainova $\mathbf{N H}^{1}$ \\ ${ }^{1}$ Praktisi Keperawatan FIKKES UNIMUS
}

Email : tri.hartiti@unimus.ac.id

\begin{abstract}
ABSTRAK
Profesionalisasi keperawatan merupakan proses dinamis dimana profesi keperawatan yang telah terbentuk mengalami perubahan dan perkembangan karakteristik sesuai dengan tuntutan profesi dan kebutuhan masyarakat. Instrumen yang dapat digunakan untuk mengukur nilai profesional seorang perawat atau mahasiswa perawat, yakni Nurses Professional Values Sclae-Revised (NPVS-R). Instrumen ini disusun dan dikembangkan sedemikian rupa, sehingga tersusunlah 28 pernyataan positif dengan skala likert untuk faktor analisis yang merupakan turunan dari kode etik keperawatan yakni caring, avtivism, trust, profesionalism, dan justice mengukur nilai profesional keperawatan. Tujuan penelitian ini adalah mengetahui nilai profesional perawat pada Mahasiswa Profesi Ners Universitas Muhammadiyah Semarang. Jenis penelitian ini adalah penelitian analitik deskriptif kuantitatif dengan Metode observasional dengan populasi adalah semua Mahasiswa Profesi Ners Universitas Muhammadiyah Semarang kelas khusus sebanyak 47 mahasiswa, dengan teknik sampling total sampling. Hasil penelitian menunjukkan sebagian besar responden mempunyai nilai caring baik sebanyak 25 responden (53,2\%), sebagian besar respon mempunyai nilai activism baik sebanyak 27 responden (57,4\%), sebagian besar responden mempunyai nilai profesionalism baik sebanyak 26 responden (55,3\%).
\end{abstract}

Kata kunci : Nilai Profesionalitas Keperawatan, caring, activism, professionalism, mahasiswa Ners

\section{ABSTRACT}

Nursing professionalization is a dynamic process in which the nursing profession that has been formed experiences changes and development characteristics in accordance with the demands of the profession and the needs of the community. Instruments that can be used to measure the professional value of a nurse or student nurse, namely Nurses Professional Values Sclae-Revised (NPVS-R). This instrument is structured and developed in such a way, so that 28 positive statements are arranged with a Likert scale for analysis factors which are derivatives of the nursing code of ethics namely caring, avtivism, trust, profesionalism, and justice measuring the value of nursing professionals. The purpose of this study was to find out the description of the value of nursing professionals at the Professional Professors of Muhammadiyah University Semarang. This type of research is quantitative descriptive analytic research with observational method which is to get an accurate picture of a number of characteristics of the problem under study. The population in this study were all Ners Professional Students of the University of Muhammadiyah Semarang as many as 47 students with total sampling technique. Univariate frequency distribution analysis technique. The results showed that most respondents had good caring values as many as 25 respondents $(53.2 \%)$, most of the responses had good activism scores of 27 respondents (57.4\%), most respondents had good professionalism as many as 26 respondents (55, 3\%).

Keyword : Value of Professionalism Nursing, Caring, Activism, Professionalism, Ners 


\section{PENDAHULUAN}

Tenaga Kesehatan Profesi Ners
merupakan aspek penting dalam
pembangunan kesehatan. Tenaga Kesehatan
Profesi Ners merupakan salah satu tenaga
kesehatan, bahkan dalam penyelenggaraan
pelayanan kesehatan tenaga perawat merupakan tenaga kesehatan terbesar yang dalam kesehariannya selalu berhubungan langsung dengan pasien dan tenaga kesehatan lainnya. Tenaga Kesehatan Profesi Ners merupakan salah satu profesi tenaga kesehatan yang memberikan pelayanan kesehatan langsung baik kepada individu, keluarga dan masyarakat secara profesional. Nilai profesionalisme merupakan nilai-nilai yang sudah di tanamkan di dalam diri Tenaga Kesehatan Profesi Ners sejak menempuh pendidikan sebagai wujud identitas dan landasan dalam bertindak. Nilai profesional tersebut menjadi pondasi dalam berhubungan dengan orang lain dan mengimplementasikan asuhan keperawatan (Potter \& Perry, 2005).

American Association of Colleges of Nursing (AACN) telah menyusun tujuh nilai esensial yang menjadi nilai profesional Tenaga Kesehatan Profesi Ners dalam melakukan asuhan keperawatan. Ketujuh nilai tersebut ialah altruisme, persamaan, estetika, kebebasan, martabat manusia, keadilan, dan kebenaran. Nilai tersebut mempengaruhi cara Tenaga Kesehatan Profesi Ners dalam berinteraksi dengan pasien dan menggunakan dirinya sebagai theraupetic use of self. Selain itu, nilai-nilai tersebut membangun bingkai idealisasi terhadap sosok perawat (Potter \& Perry, 2005).

Beberapa faktor yang memperlambat perkembangan perawat secara profesional yaitu antithetical terhadap perkembangan ilmu keperawatan, rendahnya rasa percaya diri/harga diri dengan adanya pernyataan bahwa perawat adalah pembantu dokter hal ini dikarenakan masih rendahnya ilmu pengetahuan perawat, kurangnya pemahaman dan sikap untuk melaksanakan riset keperawatan, pendidikan keperawatan hanya difokuskan pada pelayanan kesehatan yang sempit, dan rendahnya standar gaji perawat, serta sangat minimnya perawat yang menduduki pimpinan di institusi pendidikan. Faktor-faktor ini dikhawatirkan akan memengaruhi persepsi mahasiswa keperawatan untuk menjadi seorang perawat profesional dimasa akan datang (Nursalam, 2011).

Penerapan nilai keperawatan profesional (care provider, communicator, educator dan health promotor, manager dan leader, researcher) juga harus dilakukan pada mahasiswa Profesi Ners. Keterlibatan mahasiswa Profesi Ners dalam keperawatan harus disertai dengan nilai profesionalitas itu sendiri, sehingga tindakan-tindakan keperawatan yang dilakukan oleh Profesi Ners dalam keperawatan dapat dipertanggungjawabkan. Selain itu, penerapan nilai profesionalitas keperawatan pada mahasiswa Profesi Ners juga sebagai bentuk pendidikan dan persiapan dalam memasuki dunia kerja selanjutnya.

Weis \& Schank (2009) menyusun sebuah instrumen yang dapat digunakan untuk mengukur nilai profesional seorang perawat atau mahasiswa perawat, yakni Nurses Professional Values Sclae-Revised (NPVS-R). Instrumen ini disusun dan dikembangkan sedemikian rupa, sehingga tersusunlah 28 pernyataan positif dengan skala likert untuk faktor analisis yang merupakan turunan dari kode etik keperawatan yakni caring, avtivism, trust, profesionalism, dan justice mengukur nilai profesional keperawatan. Instrumen ini terdiri dari lima faktor analisis yang merupakan turunan dari kode etik keperawatan yakni caring, activism, trust, profesionalism, dan justice. Berdasarkan penelitian Noviani (2016) dengan judul 
persepsi Mahasiswa Profesi Ners tentang kode etik keperawatan Indonesia di Rumah Sakit Pendidikan Universitas Muhammadiyah Yogyakarta menunjukan bahwa persepsi mahasiswa Profesi Ners dalam kategori baik. Mereka menganggap bahwa kode etik sebagai pedoman perilaku baik perawat Indonesia dalam memberikan asuhan keperawatan. Fungsi kode etik sebagai pedoman, pengatur dan pembatas tindakan perawat.

Penelitian Sari (2017) dengan judul Hubungan Persepsi Mahasiswa tentang Profesi Keperawatan dengan Motivasi Melanjutkan Pendidikan Profesi Ners di PSIK Universitas Jember menunjukan mahasiswa yang memiliki persepsi negatif tentang profesi keperawatan sebanyak $52,6 \%$. Mahasiswa yang memiliki motivasi kurang untuk melanjutkan penddikan profesi ners yaitu sebanyak 50,5\%. Hasil penelitian ini menunjukkan nilai $p$-value $(0,003<\alpha$ $0.05)$ yang berarti terdapat hubungan antara persepsi mahasiswa tentang profesi keperawatan dengan motivasi melanjutkan pendidikan profesi. Banyak faktor yang dapat mempengaruhii motivasi mahasiswa, salah satunya yaitu persepsi. Persepsi merupakan atribut pribadi yang dihasilkan oleh kemampuan kognitif yang dimiliki seseorang.

Penelitian Naziruddin

menunjukkan ada hubungan antara motivasi vokasional, motivasi akademik dan motivasi kebutuhan dasar dengan komitmen mereka terhadap nilai-nilai moral dalam praktik adalah besar dan signifikan $(p<0.05)$. Kompetensi calon perawat yang diukur dari prestasi hasil belajar, komitmen mahasiswa terhadap nilai-nilai moral dalam praktik, dan ciri-ciri kepemimpinan efektif, dikaitkan dengan motivasi vokasional, motivasi akademik dan motivasi kebutuhan dasar, serta pengaruh aspek-aspek sosiodemografi.

Berdasarkan uraian diatas, maka Peneliti merasa tertarik untuk mengambil sebuah penelitian dengan judul "Studi Deskriptif Nilai Profesional Keperawatan Pada Mahasiswa Profesi Ners Universitas Muhammadiyah Semarang”.

\section{METODE PENELITIAN}

Jenis penelitian ini adalah penelitian analitik deskriptif kuantitatif dengan metode observasional yaitu untuk mendapatkan gambaran yang akurat dari sejumlah karakteristik masalah yang diteliti dengan pendekatan survei. Populasi dalam penelitian ini adalah semua Mahasiswa Profesi Ners Universitas Muhammadiyah Semarang kelas khusus sebanyak 47 mahasiswa dengan teknik pengambilan sampel menggunakan teknik total sampling (pengambilan sampel secara keseluruhan). Sampel dalam penelitian ini sebanyak 47 responden.

Pengambilan data pada penelitian ini menggunakan instrumen Nurse Professional Values Scale-Revised yang terdiri dari 28 item pertanyaan yang diadopsi dari journal Nurse Professional Values Scale-Revised (NPVS-R) yang dikembangkan oleh Weis \& Schank pada tahun 2009, yang selanjutnya dilakukan dengan menggunakan Skala Likert dimana setiap penilainya dari masingmasing pertanyaan jika, tidak penting diberi nilai 1 , agak penting diberi nilai 2 , penting diberi nilai 3, sangat penting diberi nilai 4 , paling penting diberi nilai 5 .

\section{HASIL DAN PEMBAHASAN}

\section{a. Karakteristik responden}

Tabel.1.Karakteristik responden berdasarkan tempat praktek Pada Mahasiswa Profesi Ners kelas khusus Universitas Muhammadiyah Semarang Tahun $2018(\mathrm{n}=47)$

\begin{tabular}{cccc}
\hline No & Tempat praktek & f & $\%$ \\
\hline 1 & RSU PKU & 21 & 55,3 \\
& Muhammadiayah \\
Gubug & & \\
2 & $\begin{array}{c}\text { RSUD Ashari } \\
\text { Pemalang }\end{array}$ & 26 & 44,7 \\
\hline
\end{tabular}


Mahasiswa Ners kelas khusus Fikkes Unimus berjumlah 47 orang, 21 orang $(55,3 \%)$ berasal dari RSU PKU Muhammadiyah gubug, dan 26 (44,7\%)orang berasal dari RSUD Ashari pemalang

Tabel.2.Karakteristik responden berdasarkan usia Pada Mahasiswa Profesi Ners kelas khusus Universitas Muhammadiyah Semarang Tahun $2018(n=47)$

\begin{tabular}{cccccc}
\hline Variabel & Mean & Median & Min & Maks & SD \\
\hline Usia & 29,34 & 30 & 29 & 54 & 4,06 \\
\hline
\end{tabular}

Rerata usia mahasiswa Ners kelas khusus Fikkes Unimus adalah 29,34 tahun, usia termuda 29 tahun dan usia tertua 54 tahun

Tabel.3.Karakteristik responden berdasarkan Jenis kelamin Pada Mahasiswa Profesi Ners kelas khusus Universitas Muhammadiyah Semarang Tahun $2018(\mathrm{n}=47)$

\begin{tabular}{llcccccc}
\hline No & Jenis kel & $\begin{array}{c}\text { Kelas RS } \\
\text { Gubug }\end{array}$ & \multicolumn{2}{c}{$\begin{array}{c}\text { Kelas } \\
\text { RSUD } \\
\text { PML }\end{array}$} & TOTAL \\
\cline { 3 - 8 } & & f & \% & f & \% & f & \% \\
\hline 1 & Laki-laki & 6 & 12,7 & 12 & 25,6 & 18 & 38,3 \\
2 & Perempuan & 15 & 31,9 & 14 & 29,8 & 29 & 61,7 \\
\hline \multirow{3}{*}{} & Total & 21 & 44,6 & 26 & 54,4 & 47 & 100 \\
\hline
\end{tabular}

Jenis kelamin mahasiswa Ners kelas khusus Fikkes Unimus sebagian besar adalah perempuan yaitu sebanyak 29 orang $(61,7 \%)$, sisanya adalah laki laki yaitu sejumlah 18 orang $(38,3 \%)$

\section{b. Nilai Caring Pada Mahasiswa Profesi Ners kelas khusus Universitas Muhammadiyah Semarang}

Hasil studi deskriptif nilai caring pada mahasiswa Profesi Ners Universitas
Muhammadiyah Semarang disajikan dalam tabel berikut ini:

Tabel 4.

Frekuensi Nilai Caring Pada Mahasiswa Profesi Ners kelas khusus Universitas Muhammadiyah Semarang Tahun $2018(\mathrm{n}=47)$

\begin{tabular}{ccccccc}
\hline \multirow{2}{*}{ Nilai } & \multicolumn{2}{c}{$\begin{array}{c}\text { Kelas RS } \\
\text { Gubug }\end{array}$} & \multicolumn{2}{c}{ Kelas RS } & \multicolumn{2}{c}{ Total } \\
Caring & $\mathbf{f}$ & $\mathbf{( \% )}$ & $\mathbf{f}$ & $\mathbf{( \% )}$ & $\mathbf{f}$ & $\mathbf{( \% )}$ \\
\hline Baik & 13 & 27,7 & 13 & 27,7 & 26 & 55,4 \\
Kurang & 9 & 19,1 & 12 & 25,5 & 21 & 44,6 \\
Baik & & & & & & \\
\hline Jumlah & $\mathbf{2 1}$ & $\mathbf{4 4 , 6}$ & $\mathbf{2 6}$ & $\mathbf{5 5 , 4}$ & $\mathbf{4 7}$ & $\mathbf{1 0 0}$ \\
\hline
\end{tabular}

Berdasarkan tabel 1. diatas dapat dilihat bahwa responden yang mempunyai nilai caring baik sebanyak 26 responden $(55,4 \%)$, sedangkan responden yang mempunyai nilai caring kurang baik sebanyak 21 responden $(44,6 \%)$. Nilai rata-rata (mean) caring perawat mendekati nilai 35 . Hal ini dapat diartikan bahwa nilai caring perawat baik. Semakin mendekati angka 35, maka nilai caring semakin baik (Weis \& Schank, 2009). Lebih banyaknya mahasiswa yang memiliki nilai caring diatas rata-rata dapat dimaknai bahwa nilai caring mahasiswa responden semakin baik. Menurut pengamatan peneliti, hal tersebut dapat dikarenakan Universitas Muhammadiyah Semarang telah menyelenggarakan praktek lapangan sebagai early clinical exposure. Sehingga program tersebut membuat mahasiswa lebih dini dan lebih banyak berinteraksi dengan pasien serta mengasah dan mengimplementasikan nilai caring. Hal lain yang ikut mempengaruhi baiknya nilai caring disebabkan karena responden adalah mahasiswa jalur khusus, dimana sudah mempunyai banyak pengalaman karena telah melakukan praktek keperawatan secara langsung di lingkungan kerja. 
Hasil penelitian menunjukkan bahwa terdapat nilai caring yang kurang baik pada Mahasiswa Profesi Ners Universitas Muhammadiyah Semarang nilai caring tersebut adalah menghormati HAM, kemanusiaan dan harga diri orang lain dengan nilai paling rendah yaitu 63 , kemudian diikuti nilai tanggung jawab dan tanggung gugat terhadap praktik yang dilakukan dengan nilai 76. Nilai caring baik tersebut meliputi menghormati HAM kemanusiaan dan harga diri oranglain, menjaga kesehatan dan keselamatan orang lain, tanggung jawab dan tanggung gugat terhadap praktik yang dilakukan, melindungi hak responden yang digunakan dalam penelitian.

Sedangkan nilai caring kurang baik tersebut meliputi melindungi hakhak moral dan legal pasien, bertindak sebagai pendamping (advokat) bagi pasien, melindungi hak-hak pasien dan menjaga rahasia pasien. Nilai caring kurang baik tersebut disebabkan karena responden merasa sebagai mahasiswa praktik yang tidak mempunyai kewenangan penuh untuk bertindak sebagai advokat bagi pasien.

Sebagai perawat, sangat penting dan menentukan untuk memahami konsep caring dan mampu menanamkan dalam hati, disirami dan dipupuk untuk mampu memperlihatkan kemampuan soft skill sebagai perawat, yaitu empati, bertanggung jawab dan tanggung gugat, dan mampu belajar seumur hidup. Semua akan berhasil dicapai oleh perawat kalau mereka mampu memahami apa itu caring. Saat ini, caring adalah isu besar dalam profesionalisme keperawatan. Caring mendeskripsikan tentang keperawatan dasar dimana perawat akan mendalami konsep sebagai dasar ilmu keperawatan. Diharapkan perawat mampu memahami tentang pentingnya perilaku caring sebagai dasar yang harus dikuasai oleh perawat.

c. Nilai Activism Pada Mahasiswa Profesi Ners kelas khusus Universitas Muhammadiyah Semarang

Hasil studi deskriptif nilai activism pada mahasiswa Profesi Ners Universitas Muhammadiyah Semarang disajikan dalam tabel berikut ini:

Tabel 5. Frekuensi Nilai Activism Pada Mahasiswa Profesi Ners kelas khusus Universitas Muhammadiyah Semarang Tahun $2018(n=47)$

\begin{tabular}{ccccccc}
\hline \multirow{2}{*}{$\begin{array}{c}\text { Nilai } \\
\text { Activism }\end{array}$} & \multicolumn{2}{c}{$\begin{array}{c}\text { Kelas RS } \\
\text { Gubug }\end{array}$} & \multicolumn{2}{c}{$\begin{array}{c}\text { Kelas RS } \\
\text { Pemalang }\end{array}$} & \multicolumn{2}{c}{ Total } \\
\cline { 2 - 7 } & $\mathbf{f}$ & $\mathbf{( \% )}$ & $\mathbf{f}$ & $\mathbf{( \% )}$ & $\mathbf{f}$ & $\mathbf{( \% )}$ \\
\hline Baik & 15 & 31,9 & 12 & 25,5 & 27 & 57,4 \\
Kurang & 6 & 12,8 & 14 & 29,8 & 20 & 42,6 \\
Baik & & & & & & \\
\hline Jumlah & $\mathbf{2 1}$ & $\mathbf{4 4 , 7}$ & $\mathbf{2 6}$ & $\mathbf{5 5 , 3}$ & $\mathbf{4 7}$ & $\mathbf{1 0 0}$ \\
\hline
\end{tabular}

Berdasarkan tabel 5. diatas dapat dilihat bahwa responden yang mempunyai nilai activism baik sebanyak 27 responden (57,4\%), sedangkan responden yang mempunyai nilai activism kurang baik sebanyak 20 responden $(42,6 \%)$. Berdasarkan hasil penelitian diatas menunjukkabn bahwa nilai rata-rata (mean) activism perawat mendekati nilai 50. Hal ini dapat diartikan bahwa nilai activism perawat baik. Semakin mendekati angka 50, maka nilai activism semakin baik (Weis \& Schank, 2009).

Hasil penelitian menunjukkan bahwa terdapat nilai activism yang kurang baik pada Mahasiswa Profesi Ners Universitas Muhammadiyah, nilai activism tersebut adalah meningkatkan profesionalitas melalui keterlibatan dalam kegiatan terkait dengan kesehatan dengan nilai paling rendah yaitu 75 , kemudian diikuti nilai berpartisipasi dalam berbagai usaha profesional dan 
interaksi kolaboratif untuk menjaga kualitas layanan dan kepuasan masyarakat terhadap layanan kesehatan dan berkonsultasi/ berkolaborasi untuk memberikan layanan kesehatan yang optimal bagi masyarakat dengan nilai 76.

Nilai activism baik tersebut meliputi berpartisipasi dalam proses peer review (penilaian sejawat), memiliki keinginan untuk terus belajar untuk selalu memperbarui pengetahuan dan keterampilan terkini, berpartisipasi dalam berbagai riset di bidang keperawatan dan/ atau mengimplementasikan temuan riset yang telah dilakukan, secara aktif ikut meningkatkan kesehatan masyarakat, ikut berperan dalam memberikan pengaruh pada anggota dewan (legislator) atau pemangku kebijakan lainnya demi peningkatan layanan kesehatan. Sedangkan nilai activism kurang baik tersebut meliputi melakukan evaluasi diri sendiri mengenai (praktik) yang sedang berlangsung, meningkatkan profesionalitas melalui keterlibatan dalam kegiatan terkait dengan kesehatan, berpartisipasi dalam berbagai usaha profesional dan interaksi kolaboratif untuk menjaga kualitas layanan dan kepuasan masyarakat terhadap layanan kesehatan, memberikan dukungan terhadap sejawat dan interaksi kolegial untuk menjaga kualitas layanan dan kepuasan masyarakat terhadap layanan kesehatan, berkonsultasi/ berkolaborasi untuk memberikan layanan kesehatan yang optimal bagi masyarakat.

Nilai activism kurang baik tersebut disebabkan karena responden merasa sebagai mahasiswa praktik yang tidak mempunyai kewenangan penuh untuk melakukan kolaborasi medis dengan tenaga media lainnya, misalnya mahasiswa tidak diberi kewenangan untuk menghubungi dokter secara langsung melalui telepon untuk melakukan kolaborasi medis.

Adanya keterbatasan nilai activism tersebut tentu perlu disiasti. Salah satu siasat yang dapat dilakukan adalah meningkatkan peran dan fungsi dari organisasi di tingkat mahasiswa. Peningkatan peran dan fungsi yang dimaksud ialah menyelenggarakan kegiatan-kegiatan yang membahas seputar isu dan kebijakan dalam keperawatan, baik dalam bentuk seminar, dikusi umum, dan sebagainya. Selain itu, untuk mengembangkan kemampuan mengadvokasi profesi, mahasiswa perlu terlebih dahulu memahami tentang faktor budaya, sosial, dan politik yang memberikan dampak dan pengaruh kepada praktik keperawatan dan profesi (Dyal \& Cohen, 2014). Untuk meningkatkan pemahaman mahasiswa tersebut, dapat digunakan konsep final project yang dilakukan mahasiswa dengan menginvestigasi kebijakan-kebijakan terkait, pembiayaan, pendidikan, hingga efektifitas pelayanan keperawatan di lapangan. Final project tersebut diakhiri dengan presentasi hasil yang dikemas dalam sebuah seminar. Cara tersebut terbukti efektif dalam meningkatkan nilai aktivisme mahasiswa (Dyal \& Cohen, 2014).

d. Nilai Profesionalism Pada Mahasiswa Profesi Ners kelas khusus Universitas Muhammadiyah Semarang

Hasil studi deskriptif nilai profesionalism pada mahasiswa Profesi Ners Universitas Muhammadiyah Semarang disajikan dalam tabel berikut ini: 
Tabel 6.

Frekuensi Nilai Profesionalism Pada

Mahasiswa Profesi Ners kelas khusus Universitas Muhammadiyah Semarang Tahun $2018(n=47)$

\begin{tabular}{ccccccc}
\hline \multirow{2}{*}{$\begin{array}{c}\text { Nilai } \\
\text { Activism }\end{array}$} & \multicolumn{2}{c}{$\begin{array}{c}\text { Kelas RS } \\
\text { Gubug }\end{array}$} & \multicolumn{2}{c}{$\begin{array}{c}\text { Kelas RS } \\
\text { Pemalang }\end{array}$} & \multicolumn{2}{c}{ Total } \\
\cline { 2 - 7 } & $\mathbf{f}$ & $\mathbf{( \% )}$ & $\mathbf{f}$ & $\mathbf{( \% )}$ & $\mathbf{f}$ & $\mathbf{( \% )}$ \\
\hline Baik & 14 & 29,8 & 12 & 25,5 & 26 & 55,3 \\
Kurang & 7 & 14,9 & 14 & 29,8 & 21 & 44,7 \\
Baik & & & & & & \\
\hline Jumlah & $\mathbf{2 1}$ & $\mathbf{4 4 , 7}$ & $\mathbf{2 6}$ & $\mathbf{5 5 , 3}$ & $\mathbf{4 7}$ & $\mathbf{1 0 0}$ \\
\hline
\end{tabular}

Berdasarkan tabel 6. diatas dapat dilihat bahwa responden yang mempunyai nilai activism baik sebanyak 26 responden (55,3\%), sedangkan responden yang mempunyai nilai activism kurang baik sebanyak 21 responden $(44,7 \%)$.

Berdasarkan hasil penelitian diatas menunjukkan bahwa nilai ratarata (mean) profesionalism perawat mendekati nilai 55. Hal ini dapat diartikan bahwa nilai profesionalism perawat baik. Semakin mendekati angka 55, maka nilai profesionalism semakin baik (Weis \& Schank, 2009).

Hasil penelitian menunjukkan bahwa terdapat nilai profesionalism yang kurang baik pada Mahasiswa Profesi Ners Universitas Muhammadiyah, nilai profesionalism tersebut adalah berinisiatif untuk melakukan tindakan (yang positif) di lingkungan praktik dengan nilai paling rendah yaitu 75 , kemudian diikuti nilai menjunjung tinggi sikap yang bertanggung jawab dan bertanggungjawab untuk memenuhi berbagai layanan kesehatan bagi masyarakat yang majemuk (SARA) dengan nilai 76 .

Nilai profesionalism baik tersebut meliputi melaksanakan standar praktik sesuai dengan pedoman yang berlaku, meningkatkan dan melaksanakan standar sesuai dengan aturan yang berlaku di tempat praktik, mengenali peran asosiasi ners profesionalitas dalam menetapkan kebijakan dalam hal kesehatan, membangun kerjasama kolaboratif untuk mengurangi kesenjangan dalam memberikan layanan kesehatan, melaksanakan praktik dengan bimbingan secara taat dan disiplin, mengenai batasan- batasan nilai profesionalisme. Sedangkan nilai profesionalism kurang baik tersebut meliputi menjunjung tinggi sikap yang bertanggung jawab, berinisiatif untuk melakukan tindakan (yang positif) di lingkungan praktik, bertanggungjawab untuk memenuhi berbagai layanan kesehatan bagi masyarakat yang majemuk (SARA), memberikan layanan tanpa pandang bulu terhadap kondisi pasien atau masyarakat, berani menghadapi dokter/tenaga kesehatan yang meragukan atau tidak sesuai. Nilai profesionalism kurang baik tersebut disebabkan karena responden merasa sebagai mahasiswa praktik yang tidak mempunyai kewenangan penuh dalam memegang tanggung jawab terhadap pasien, dan tidak bias bebas melakukan tindakan dengan inisiatif diri sendiri.

Lebih banyaknya mahasiswa yang memiliki nilai profesionalism diatas rata-rata dapat dimaknai bahwa nilai profesionalism mahasiswa responden semakin baik. Menurut pengamatan peneliti, hal tersebut dapat dikarenakan Universitas Muhammadiyah Semarang telah menyelenggarakan Program Praklinik sebagai early clinical exposure. Sehingga program tersebut membuat mahasiswa lebih dini dan lebih banyak berinteraksi dengan pasien serta mengasah dan mengimplementasikan 
nilai profesionalism. Hal lain yang ikut mempengaruhi baiknya nilai profesionalism disebabkan karena responden adalah mahasiswa jalur khusus, dimana sudah mempunyai banyak pengalaman karena telah melakukan praktek keperawatan secara langsung di lingkungan kerja.

Komponen nilai profesionalism ini diwujudkan dengan ditegakkannya standar-standar praktik dalam pelaksanaan praktik, menginisiasi diri untuk menciptakan dan meningkatkan lingkungan praktik yang tepat dan baik, hingga terlibat langsung dalam evaluasi teman sejawat secara obyektif (Weis \& Schank, 2009). Dehghani (2015) menemukan ada tiga pilar yang membangun profesionalisme dalam keperawatan, yakni prinsip kepedulian, komunikasi, dan etik. Profesionalisme perawat juga ditentukan oleh tiga hal penting, yakni kognitif, sopan santun, dan psikomotorik (Ghadirian, dkk, 2014).

\section{KESIMPULAN}

Sebagian besar responden mempunyai nilai caring baik sebanyak 25 responden $(53,2 \%)$, nilai activism baik sebanyak 27 responden $(57,4 \%)$. Dan nilai profesionalism baik sebanyak 26 responden (55,3\%). Diharapkan agar pihak Universitas Muhammadiyah Semarang menjadikan dasar atau bahan masukkan penelitian ini dalam mengembangkan ilmu tentang nilai profesional keperawatan pada Mahasiswa Profesi Ners, dan diharapkan para mahasiswa melakukan evaluasi diri dalam mengembangkan nilai profesional keperawatan, serta penelitian ini diharapkan dijadikan sebagai pengalaman nyata dalam melaksanakan penelitian secara ilmiah dalam rangka mengembangkan diri dalam melaksanakan fungsi perawat.

\section{DAFTAR PUSTAKA}

Alec Fisher. 2014. Berpikir Kritis: Sebuah Pengantar. Jakarta : Erlangga.

American Association of Colleges of Nursing [AACN]. 2008. The Essentials of Baccalaureate Education For Professional Nursing Practice. Washington, DC.

Arikunto, Suharsimi. 2009. Prosedur Penelitian Suatu Pendekatan Praktek. Edisi Revisi VII. Jakarta: PT Asdi Mahasatya.

Asmadi. 2008. Konsep Dasar Keperawatan. Jakarta : EGC.

Azwar, S. 2015. Penyusunan Skala Psikologi. Edisi 2. Yogyakarta: Pustaka Belajar.

Djojodibroto, R.D. 2004. Tradisi Kehidupan Akademik. Yogyakarta: Galang Press.

Ganda, Yahya. 2004. Petunjuk Praktis Cara Mahasiswa Belajar di Perguruan Tinggi. Jakarta: Grasindo.

Long, Barbara C. 2006. Perawatan Medikal Bedah (Suatu Pendekatan Proses Keperawatan). Jilid 3. Bandung : Yayasan Ikatan Alumni Pendidikan Keperawatan.

Ma, Fang., Li Jiping., Zhu, Dan., Bai, Yang juan., dan Song, Jianhua. 2013. Confronting The Caring Crisis In Clinical Practice. Medical Education: Vol. 47, hal. 1037-1047. doi: 10.1111/medu. 12250 .

Notoatmodjo, S. 2012. Metodologi Penelitian Kesehatan. Jakarta : Rineka Cipta.

Nursalam. 2011. Proses dan Dokumentasi Keperawatan, Konsep dan Praktek. Jakarta : Salemba Medika.

2013. Konsep Penerapan Metode Penelitian Ilmu Keperawatan. Jakarta: Salemba Medika. 
Potter, P.A, Perry, A.G. 2005. Buku Ajar Fundamental Keperawatan : Konsep, Proses, dan Praktik. Edisi 4.Volume 2.Alih Bahasa : Renata Komalasari, dkk. Jakarta : EGC.

PPNI Indonesia. 2005. Standar Kompetensi Perawat Indonesia. dari PPNI Indonesia website: http://www.inna-ppni.or.id.

Sartika \& Nanda. 2011. Konsep Caring. diambil dari http://www.pedomannews.com. Diakses 10 Januari 2018.

Setiadi. 2007. Konsep dan Penulisan Riset Keperawatan. Yogyakarta : Graha Ilmu.

Setiawan A. \& Saryono. 2010. Metodologi Penelitian Kebidanan. Yogyakarta: Nuha Medika.

Setyosari, Punaji. 2013. Metode Penelitian Pendidikan dan Pengembangan. Jakarta : Kencana Prenadamedia Group.

Waltz, e. a. 2010. Meansurement in Nursing Health Research,. New York: LCC.

Weis, D., Schank, M. J. 2009. Development and Psychometric Evaluation of the Nurses Professional Values Scale-Revised. Journal of Nursing Measurement : Vol. 17, No. 3, hal.221-231. Doi 10.1891/10613749.17.3.221.

Wood, M. J., \& Ross-Kerr, J. C. 2011. Basic steps in planning nursing research: From question to proposal (7th Ed.). Sudbury, MA: Jones and Bartlett Publishing. 